\title{
HYPHOMYCETES AND MACROINVERTEBRATES COLONIZING LEAF LITTER IN TWO BELGIAN STREAMS WITH CONTRASTING WATER QUALITY
}

\author{
Z. L. Cheng ${ }^{1}$, P. Andre' ${ }^{1} \&$ C. Chiang $^{2}$ \\ ${ }^{1}$ Unité des Eaux et Forêts, Faculté des Sciences Agronomiques. Université Catholique de Louvain, 1348 Louvain-la-Neuve. Belgique \\ ${ }^{2}$ Unité de Microbiologie, Faculté des Sciences Agronomiques, Université Catholique de Louvain, 1348 Louvain-la-Neuve, Belgique.
}

Keywords: Water chemistry, leaf litter, aquatic hyphomycetes, shredders, Gammarus.

\section{SUMMARY}

Breakdown, hyphomycete and invertebrate colonization of beech (Fagus sylvatica L.) and poplar (Populus nigra $\mathbf{x}$ euromerican Dode juinier) leaves were ctudied in two headwater streams with contrasting water chemistry. Breakdown of both species was slower in stream B, a headwater stream containing herbicides and low concentrations of metal ions. This was related to lower conidial production of aquatic hyphomycetes and lower biomass of Gammarus sp., a shredder that dominated invertebrate assemblages on leaf packs. Differences in processing rates, colonization by aquatic hyphomycetes, and shredder assemblages appeared to be related to stream water chemistry. Although the herbicide and metal concentrations in stream B were rather moderate, the activity of aquatic hyphomycetes and shredderc may have been adversely affected.

\section{INTRODUCTION}

Plant organic matter, consisting of autumn-ched leaves, represents the main energy input to stream ecocyctems (KAUSHIK \& HYNES 1968; CUMMINS, 1974). During the last three decades, numerous studies have assessed allochthonous leaf litter inputs to streams and rivers in different parts oí the world (KAUSHIK \& HYNES. 1968: BARLOCHER \& KENDRICK, 1974; CUMMINS, 1974; SUBERKROPP \& KLUG, 1976: IQBAL et al., 1979; CHAMIER, 1987; CHAUVET. 1987: CHERGUI \& PATTEE, 1991 ; GESSNER \& CHAUVET. 1994; POZO et al., 1997). Although most observations were carried out in unpolluted streams, some studies suggected ihat water chemistry may influence microbial activity and shredder colonization (TRISKA \& SEDELL. 1976: WALLACE et al., 1982: HOWELLS et al., 1983; ABEL \& BARLOCHER, 1984: CIJFFNEY et al., 1984; AU et al.. 1992; MAUND et al., 1992: GRIFFITH \& PERRY, 1993; MALTBY \& CRANE, 1994: SUBERKROPP \& CHAUVET, 1995: BERMINGHAM et al., 1996a. b). Factors which affect leaf decomposition in streams may have a vast impact on the energy and nutrient budgets of downstream areas.

Limrelica, 1,3(2): 57-6.3(1997)

J. Pozo \& A. Elosegi (eds)

Proceedings of the Eurapean Meting on Liller Breakdown in Rivers and Streams (1) Asociacion Española de Limnología. Madrid. Spain
In this study, we measured mass losses of leaves in litterbags placed in two streams diffcring in water chemistry (concentration of herbicides and metal ions). Concurrently, dynamics of aquatic hyphomycetes, and density and biomacs of macroinvertebrates colonizing the leaf bags were measured. The rnain objective was to assess whether or not slight changes in water quality affect ratec of leaf litter breakdown.

\section{MATERIALS AND METHODS}

\section{Study sites}

The ctudy area is located in the Bois de Lauzelle, a 200 ha forested watershed $\left(50^{\circ} 40^{\prime} \mathrm{N}, 4^{\circ} 37^{\prime} \mathrm{W}\right)$ in Louvain-la-Neuve, Belgium (fig. 1), drained by a second-order stream (Blanc-Ry). Several studies indicated that the tributaries reaching the BlancRy from the south differ in water chemistry from those coming from the north, and are slightly polluted with some herbicides (CHENG. 1994; LAMBERT. 1994; HALLAUX. 1995 CHENC, 1996). CHABOT (1994)described the hydrogeology of this tone: the general gradient of the groundwater runs frorn south-east to north-west in a geological layer of Bruxelliens 


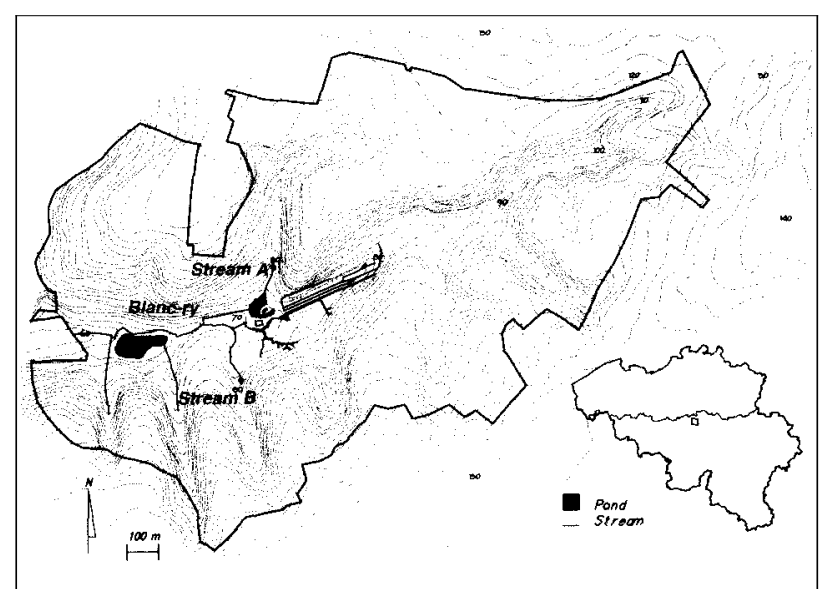

Figure 1. Location of the two study streams in the Bois de Lauzelle

sand. In addition, the groundwater layer in this zone is particularly vulnerable to deterioration because the Bruxelliens sand appears on the surface in many places without a surface silt cover (fig. 2). Herbicides and other pollutants could easily infiltrate through the surface of the southern part, where agricultural fields and scientific-industrial parks, potential sources of pollution, are located. Pollutants leached into the groundwater could eventually reach the Blanc-Ry.

Two first-order streams were selected for the study. Stream A, with a length of $110 \mathrm{~m}$, was located in the northem bank of Blanc-Ry and runs through a niixed stand of oak, maple and alder. Stream B, with a lenght of $250 \mathrm{~m}$, was located several hundred meters south from stream A, and is surrounded mainly by beech, oak and maple forest. No difference of the forest canopy can be observed between these two sites, according to standing basal area measurements: $24 \mathrm{~m}^{2}$ ha ${ }^{1}$ and $25 \mathrm{~m}^{2}$ ha 1 respectively for the catchment of stream A and stream B (DEGROOTE, 1997).

\section{Water quality}

Water samples were taken at the two sites, three times per month, from April to September 1997, a period when higher concentrations of herbicides in stream B had been reported. Field analyses included temperature (mercury thermometer), $\mathrm{pH}$ (pH-meter WTW pH 91), and conductivity (conductivity meter JENWAY 4070). Water samples were frozen and stored for further determination of anions $(\mathrm{Cl}, \mathrm{NO}, \mathrm{SO}$,) by HPLC, and cations $(\mathrm{Ca}, \mathrm{Mg}, \mathrm{K}, \mathrm{Na}, \mathrm{Cd}, \mathrm{B}, \mathrm{Fe}, \mathrm{Mn}, \mathrm{Cu}, \mathrm{Ni}, \mathrm{Al}, \mathrm{Cr}$, $\mathrm{Zn}$ ) by Flame Emission Spectrometry with Inductively Coupled Plasma (ICP) within a short period. Once a month, we tested additiorial samples for the presence of the herbicides atrazine, simazine and diuron. Water was paper filtered immediately after collection, the herbicides were concentrated by solid phase extraction (J.T. BAKER Inc., 1990), and analysed by HPLC.

\section{Litter degradation}

Leaf breakdown of two common tree species, beech (Fagus sylvatica L.) and poplar (Populus nigra nigru $\mathrm{x}$ euromerican Dode juinier.) was studied. Leaves were collected on the ground after abscission, in late autumn of 1996, and air dried. We placed 4-g samples into nylon bags $(25 \times 16 \mathrm{~cm})$, with a mesh size of $7 \times 7 \mathrm{~mm}$, large enough to permit free entry of any macroinvertebrates. Twenty-four bags of each species, tied to

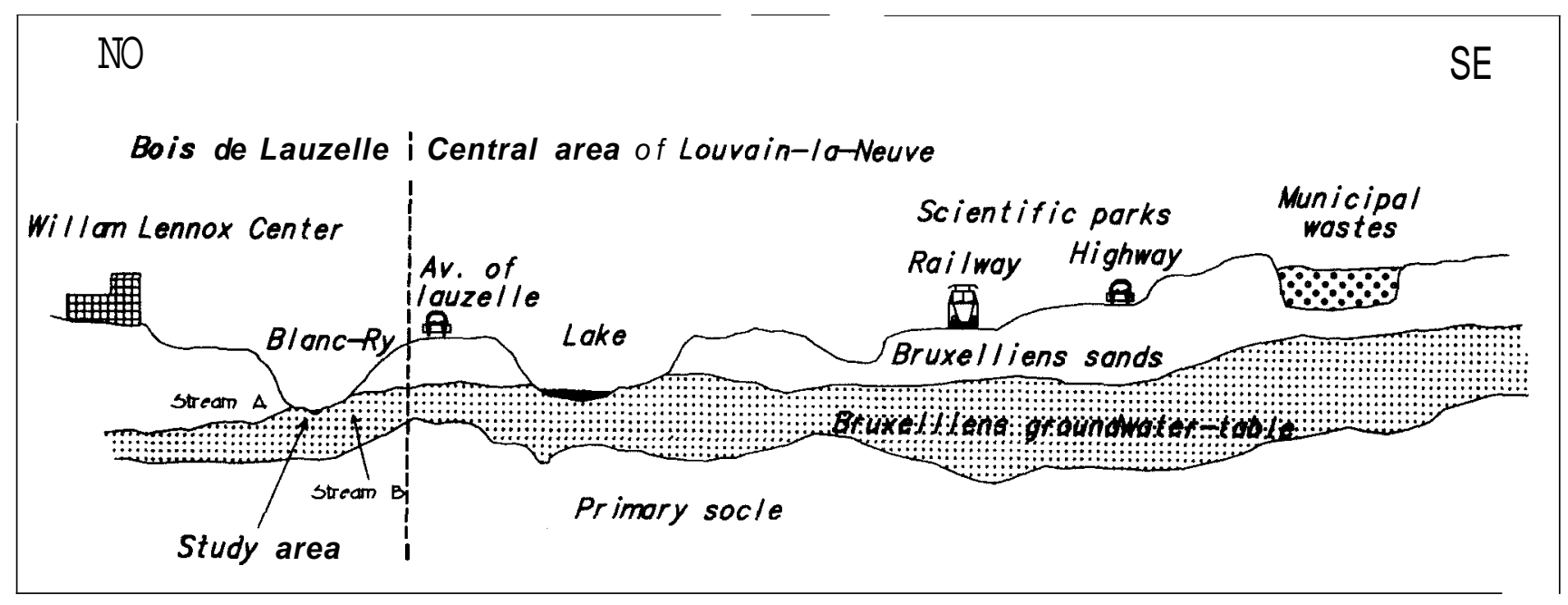

Figure 2. Hydrogeologic conditions of Louvain-la-Neuve. Belgium (After CHABOT, 1994) 
bricks, were submerged at each study cite on 7 April 1997.

Four bags of each cpecies were collected from each study site after 2 days, 2 weeks, 4 weeks, and then at 4 -week intervals until Juiy 1997. Of these four bags. one was placed in a plastic bag with stream water for analysis of aquatic hyphomycetes, which was carried within 3 hours after sampling. The remaining three mesh bags were also placed in plastic bags but not necessarily with stream water. Back in the laboratory, the leaves in the last three bags were carefully washed under flowing tap water through a $800 \mu \mathrm{m}$ sieve to remove sediment and macroinvertebrates. The macroinvertebrates were preserved in $70 \%$ ethanol for further identification. The leaves were weighed to the nearest $0.1 \mathrm{mg}$, after oven-drying at $50{ }^{\circ} \mathrm{C}$ for 48 hours. Ash-free dry mass (AFDM) determinations were made by burning a subsample of the dried remaining leaf material at $550^{\circ} \mathrm{C}$ for three hours.

\section{Aquatic hyphomycetes}

The method to analyse aquatic hyphomycetes on leaf samples was modified from WOOD-EGGENSCHWILER \& BARLOCHER (1983). At each sampling time, twenty $95 \mathrm{~mm}^{2}$ discs were cut from each species with a stainless cork borer, placed separately in flasks $(250 \mathrm{ml}$, filled with $100 \mathrm{ml}$ distilled water) and aerated for $72 \mathrm{~h}$ at $20^{\circ} \mathrm{C}$. Each leaf disc was collected, dried and weighed, and the supernatant was filtered through $5 \mu \mathrm{m}$ membrane filters. Conidia of aquatic hyphomycetes trapped on the filter were stained with $0.1 \%$ lactophenol cotton blue. The number of conidia produced per mg dry weight of leaf was determined by counting all conidia on a small section of the filters under light microscope (magnification $310 \mathrm{X}$ ). The key references used for identification were NILSSON (1964), GONCZOL (1971), INCOLD (1975) and WEBSTER \& DESCALS (1981).

\section{Macroinvertabrates}

Macroinvertebrates associated with the leaves were sorted and identified to family, genus or species. They were assigiied to functional feeding groups according to TACHET et al. (1987). Dry weight of macroinvertebrates was determined after oven drying to constant weight at $60^{\circ} \mathrm{C}$. The trichopterans were removed from their caces before weighing.

\section{Breakdown rates and data analysis}

The breakdown coefficient (k) was estimated for each leaf species in each site by regressing leaf pack mass versus time according to the exponential decay modei:

$$
\mathrm{Wt}=\mathrm{Wo}_{0} \mathrm{e}^{-\mathrm{kt}}
$$

where Wo was the initial leaf mass, Wt was leaf mass remaining at time $t$, and $\mathbf{k}$ the specific breakdown coefficient (PETERSEN \& CUMMINS, 1974). Analysis of covariance (ANCOVA) was used to compare regressions $(\mathrm{p}<0.05)$ (ZAR, 1984). Analysis of variance (ANOVA) was used to compare macroinvertebrates and aquatic hyphomycetes in different leaf bags (ZAR, 1984). Statistical calculations were performed with SYSTAT software (WILKINSON, 1990).

\section{RESULTS}

\section{Streamwater quality}

Table 1 shows the physico-chemical characteristics of stream water during the experiment. Water temperature and $\mathrm{pH}$ were similar in both streams. However, there were differences in the concentrations of some compounds such as herbicides, especially diuron, and some metal ions. Although the average of

Tahle 1. Physical and chemical characteristics of the water in the two study streams. Average values with standard deviation (SD) from April 1994 to July 1997 for herbicides, and from April to July 1997 for others.

\begin{tabular}{lcc}
\hline & Stream A & Stream B \\
Temperature $\left({ }^{\circ} \mathrm{C}\right)$ & $10.0(0.57)$ & $10.6(0.98)$ \\
$\mathrm{pH}$ & $7.31(0.09)$ & $7.35(0.17)$ \\
$\mathrm{Conductivity}\left(\mu \mathrm{s} \mathrm{cm}^{-1}\right)$ & $385(12)$ & $444(10)$ \\
$\mathrm{Ca}^{2+}\left(\mathrm{mg} \mathrm{l}^{-1}\right)$ & $66.5(2.1)$ & $63.9(7.7)$ \\
$\mathrm{Mg}^{2+}\left(\mathrm{mg} \mathrm{l}^{-1}\right)$ & $9.87(0.2)$ & $9.81(0.5)$ \\
$\mathrm{Na}^{+}\left(\mathrm{mg} \mathrm{l}^{-1}\right)$ & $13.8(2.1)$ & $24.3(2.1)$ \\
$\mathrm{K}^{+}\left(\mathrm{mg} \mathrm{l}^{-1}\right)$ & $2.58(0.8)$ & $4.37(0.8)$ \\
$\mathrm{Cl}^{-}\left(\mathrm{mg} \mathrm{l}^{-1}\right)$ & $36.2(8.0)$ & $48.6(7.7)$ \\
$\mathrm{NO}_{3}{ }^{-1}\left(\mathrm{mg} \mathrm{l}^{-1}\right)$ & $18.2(5.3)$ & $18.4(5.7)$ \\
$\mathrm{SO}{ }^{2-}\left(\mathrm{mg} \mathrm{l}^{-1}\right)$ & $56.7(11.5)$ & $53.6(13.9)$ \\
$\mathrm{Atrazine}(\mathrm{ppb})$ & $<0.05(0.00)$ & $0.45(0.32)$ \\
$\mathrm{Simazine}(\mathrm{ppb})$ & $<0.05(0.00)$ & $0.45(0.36)$ \\
$\mathrm{Diuron}(\mathrm{ppb})$ & $<0.05(0.00)$ & $1.43(0.70)$ \\
$\mathrm{Al}\left(\mu \mathrm{g} \mathrm{l}^{-1}\right)$ & $0.0(0.0)$ & $2.3(6.4)$ \\
$\mathrm{B}\left(\mu \mathrm{gl}^{-1}\right)$ & $17.9(14.8)$ & $30.2(14.0)$ \\
$\mathrm{Cd}\left(\mu \mathrm{gl}^{-1}\right)$ & $11.3(5.3)$ & $11.7(4.2)$ \\
$\mathrm{Cu}\left(\mu \mathrm{gl}^{-1}\right)$ & $6.4(4.1)$ & $9.3(6.5)$ \\
$\mathrm{Cr}\left(\mu \mathrm{g} \mathrm{l}^{-1}\right)$ & $59.9(21.1)$ & $77.8(36.2)$ \\
$\mathrm{Fe}\left(\mu \mathrm{gl}^{-1}\right)$ & $3.6(2.9)$ & $4.3(2.9)$ \\
$\mathrm{Mn}\left(\mu \mathrm{g} \mathrm{l}^{-1}\right)$ & $4.3(3.9)$ & $4.9(6.3)$ \\
$\mathrm{Ni}\left(\mu \mathrm{gl}^{-1}\right)$ & $10.2(15.5)$ & $21.4(27.6)$ \\
$\mathrm{Zn}\left(\mu \mathrm{gl}^{-1}\right)$ & $23.3(11.3)$ & $24.1(20.3)$ \\
\hline
\end{tabular}


Table 2. Periodical "peak values" for metal ion concentrations $\left(\mu \mathrm{g} \mathrm{l^{-1 }}\right)$ at 3 sampling dates.

\begin{tabular}{lccc}
\hline \multirow{2}{*}{ Date } & Metal ions & Stream A & Stream B \\
$01 / 04 / 97$ & $\mathrm{Cr}$ & 52 & 131 \\
& $\mathrm{Cu}$ & 6 & 19 \\
$\mathrm{Mn}$ & 4 & 12 \\
$\mathrm{Ni}$ & 0 & 67 \\
$04 / 06 / 97$ & & & \\
& $\mathrm{Cr}$ & 57 & 133 \\
& $\mathrm{C} \mathrm{u}$ & 9 & 18 \\
$\mathrm{Mn}$ & 9 & 19 \\
$02 / 07 / 97$ & $\mathrm{Ni}$ & 18 & 73 \\
& $\mathrm{Cr}$ & 69 & 129 \\
& $\mathrm{Cu}$ & 9 & 19 \\
& $\mathrm{Mn}$ & 4 & 12 \\
$\mathrm{Ni}$ & 15 & 71 \\
\hline
\end{tabular}

some metal concentrations was not significantly different, peak values were often measured in stream B, as shown in table 2 . In addition, conductivity was also higher in stream $\mathbf{B}$.

\section{Breakdown rates}

Fig. 3 shows mass losses of leaves over time. Breakdown of both species was slower in stream B than that in stream A. In both streams, poplar decayed faster than beech. Beech mass remaining after 3 months was $57 \%$ in stream $\mathrm{B}$ and $16 \%$ in stream A, contrasting with only $23 \%$ and $6 \%$ for black poplar in streams $B$ and $\mathbf{A}$, respectively, after nearly 2 months of incubation. This difference between streams was noticeable after 14 days for poplar leaves, but only after 28 dayc for beech leaves.

All data fitted to the negative exponential model and regression coefficientc were highly significant $(\mathrm{p}<0.01)$. Breakdown rates were higher in stream A for both leaf species: $0.0533 \mathrm{~d}^{-1}$ for poplar and $0.0209 \mathrm{~d}^{-1}$ for beech, versus $0.0287 \mathrm{~d}^{-1}$ and $0.0051 \mathrm{~d}^{-1}$ in stream B. Analysis of covariance (ANCOVA) showed that all four breakdown rates were significantly different (table 3).

\section{Aquatic hyphomycetes}

A total of 20 species belonging to 12 genera of aquatic hyphomycetes were found on leaf bags. The five dominant species in both streams were Alatospora acuminata, Clavariopsis aquatica. Articulospora tetracladia. Anguillospora longissima, and Dactylella submersa. The conidial production on leaves was significantly higher in stream A than in B (ANOVA, $\mathrm{p}<0.05$, fig. 4). Fungal colonization was slower on beech leaves, but

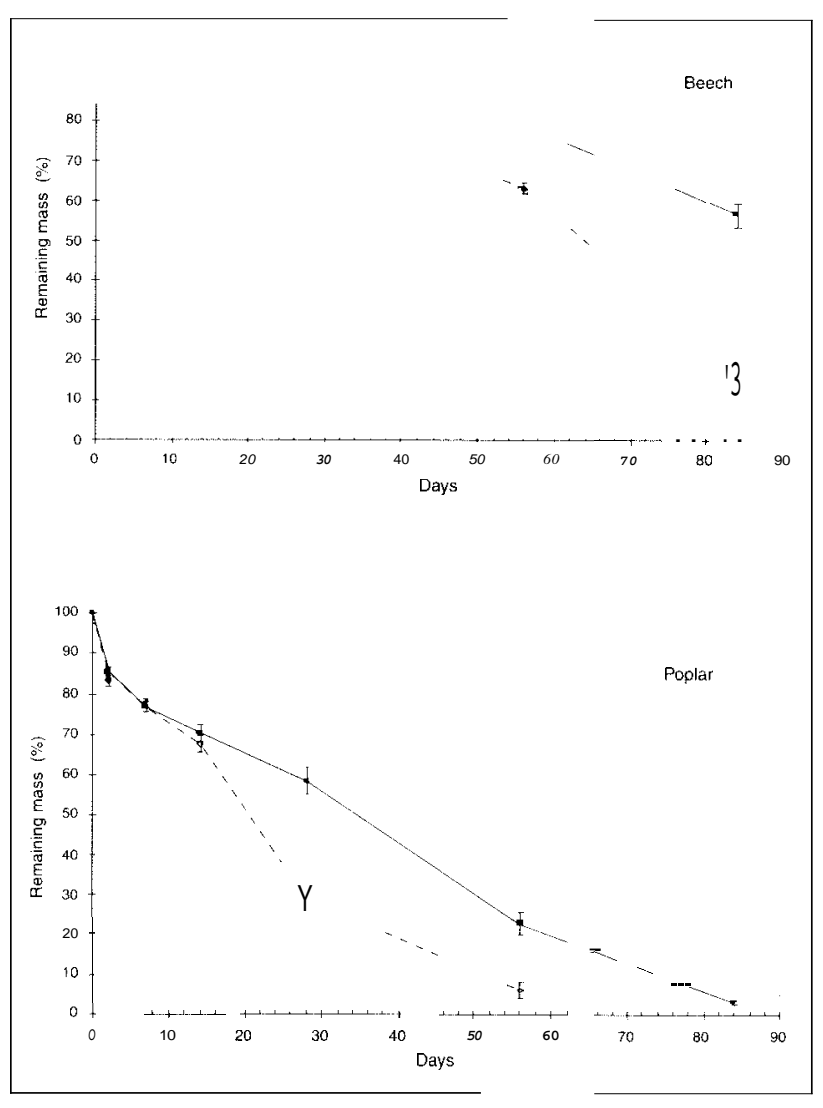

Figure 3. Remaining mass (\%) of leaf bags in the study streams: -.. Stream A, - Stream B. Error bars represent SD $(n=3)$.

Table 3. Breakdown rates $\left(\boldsymbol{k}, \mathrm{d}^{-1}\right)$ of leaf litter in the two study strearns. All four rates are significantly different (ANCOVA, Tukey's comparison).

\begin{tabular}{ccc}
\hline Streams & Beech & Poplar \\
A & 0.0209 & 0.0533 \\
B & 0.0051 & 0.0287 \\
\hline
\end{tabular}

yielded higher conidial production. The highest conidial production for both species occurred after 28 days of stream expocure.

\section{Macroinvertebrates}

Macroinvertebrates were more abundant in litter bags from stream A (fig. 5), and followed similar patterns for both leaf species. All invertebrates found were shredders, and Gammarus pulex L. amounted to more than $95 \%$ of the total. Limnephilidae, Nemouridae and Asellus sp. were also found at both sites, but in very small numbers. 


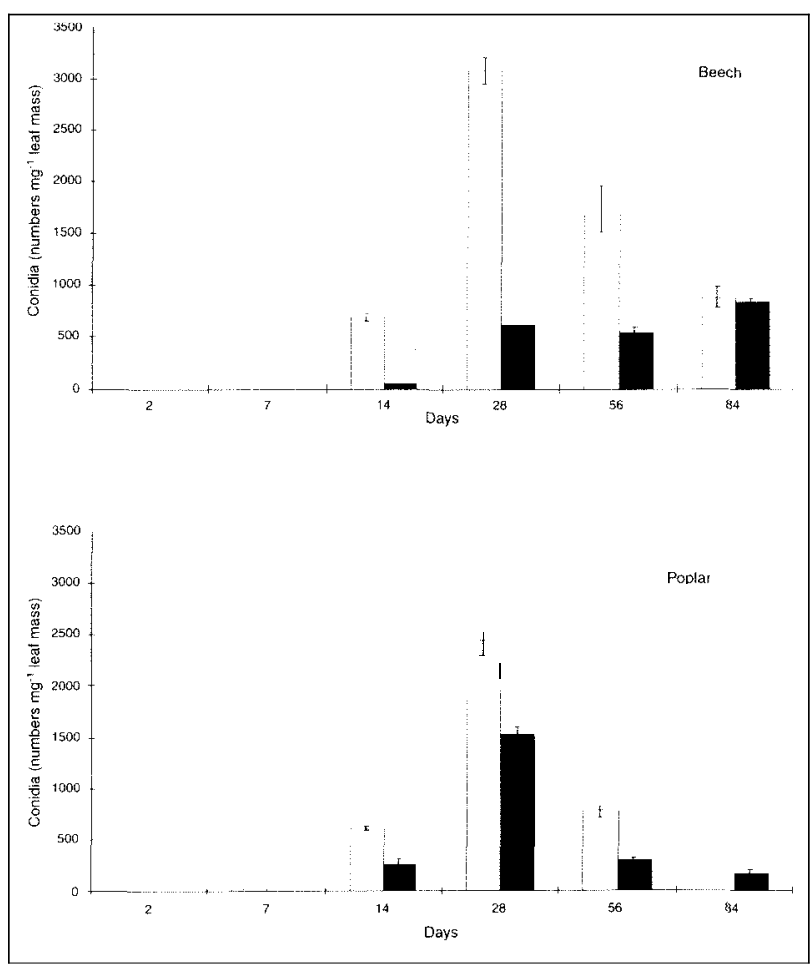

Figure 4. Average conidial numbers of aquatic hyphomycetes produced per mg of leaves in the study streama: $\square$ Stream A, $\mathbf{\square}$ Stream B. Error bars represent $\mathrm{SD}(\mathrm{n}=3)$.

Patterns of macroinvertebrate biomass were similar to thoae of density (fig. 6). Differences between streams were significant for both dencity and biomass on the two leaf species (ANOVA, $\mathrm{p}<0.05$ ).

\section{DISCUSSION}

The decomposition process has been subdivided into three distinct phases: leaching, microbial colonization and invertebrate feeding (PETERSEN \& CUMMINS, 1974). Leaching occurs mainly during the first days of incubation. In the present study, macc loss during the first two days of incubation was $6.2 \%$ for beech and $16.7 \%$ for poplar in stream $\mathbf{A}$, and $6.0 \%$ and $14.9 \%$. respectively, in stream $\mathbf{B}$.

The lower conidial production of aquatic hyphomycetes on both leaf species in stream B suggests that microbial colonization was inhibited. The chemical composition of stream B may induce a light contamination by herbicides and by some metal ions which are not favourable for these fungi. AU et al. (1992) found that conidial production on leaves decreased in reaches subjected to sewage inputs. CHAUVET et al. (1997) reported that the activity of aquatic hyphomycetes appeared to be more

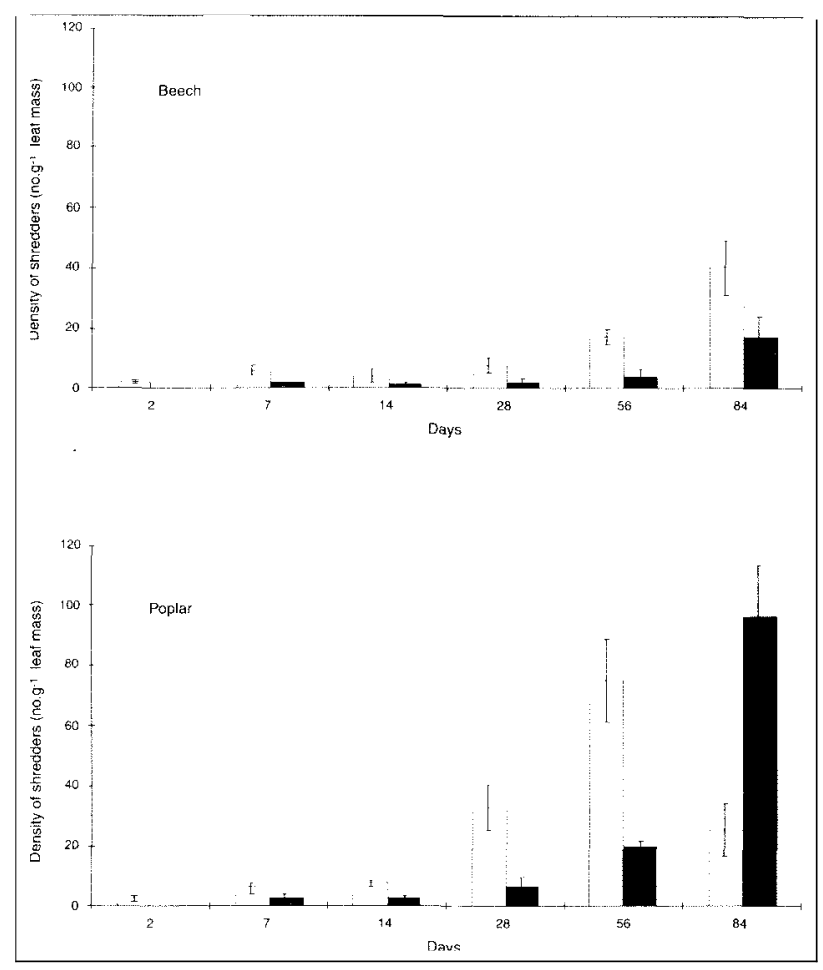

Figure 5. Density of shredders (number $\mathrm{g}^{-1}$ leaf mass) in leaf bags in the study streams: $\square$ Stream A, Stream B. Error bars represent $\operatorname{SD}(n=3)$.

affected by stream chemictry than by leaf cpecies. BERMINGHAM et al. (1996a) demonstrated that some species of aquatic hyphomycetes were absent on Alnus and Acer leaves incubated downstream of coal mine effluent and the rate of processing of both leaves therefore was reduced. It seems likely, that water chemistry instead of other factors was responsible for the lower conidial production of aquatic hyphomycetes on leaves in stream B. Direct or indirect biochemical influences of water quality, specially the chronic effect of herbicides, on the dynamics of aquatic hyphomycetes need further investigation.

Some works suggested that macroinvertebrates select leaf litter as a food source mainly in function of the microbial colonization, and more specifically of the microflora (KAUSHIK \& HYNES, 1971; MACKAY \& KALFF, 1973; BARLOCHER, 1985). Results of the present study agree with this finding. For both leaf species, the highest densities and biomass of macroinvertebrates were found in stream $\mathbf{A}$, where bags showed higher colonization by aquatic hyphomycetes. On the other hand, in stream B, where higher amounts of herbicides and metal ions are periodically observed, colonization by aquatic hyphomycetes and macroinvertebrates were much lower.

However, although we found conidial production to be higher on beech than on poplar leaves, the density and biomass of 


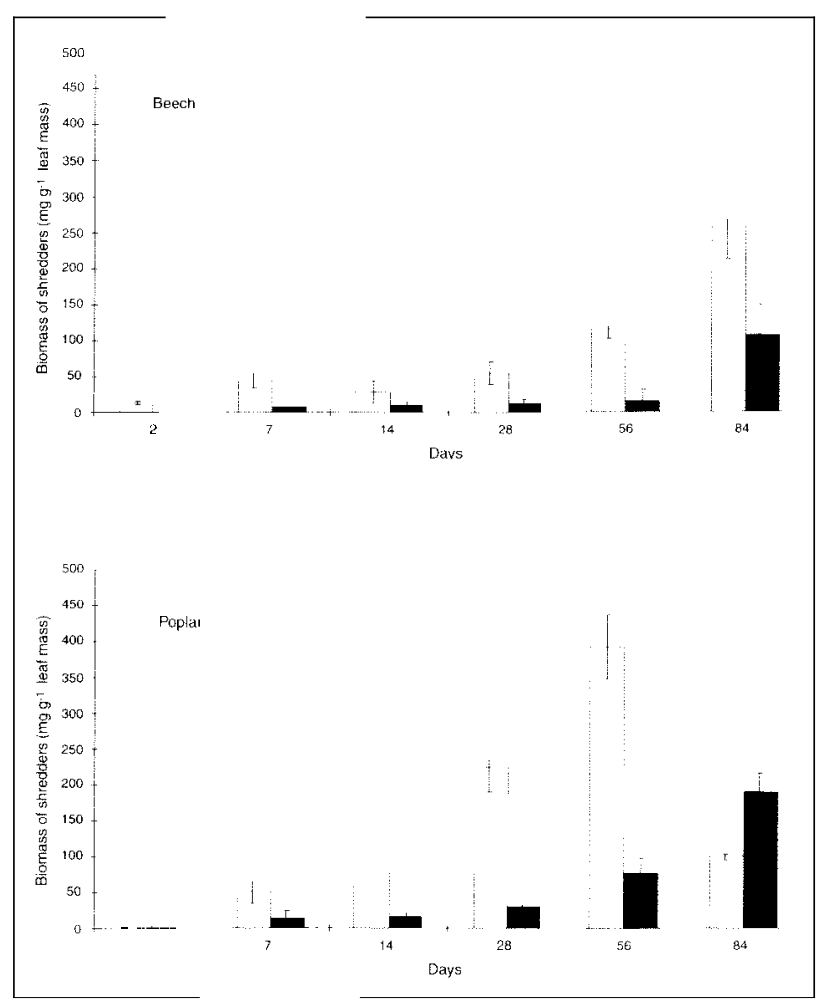

Figure 6. Biomass of shredders (mg $\mathrm{g}^{-1}$ leaf mass) in leaf bags in the study streams: $\square$ Streani A. Streani B. Error bars represent $\operatorname{SD}(n=3)$.

macroinvertebrates were higher on poplar. This phenomenon is probably related to the initial leaf quality.

Chronic exposure even to low concentrations of some metal ions decreases the growth and curvival of Gammarus sp. (MAUND et al., 1992; CRANE, 1995; PLENET, 1995). Some toxicity studies (WALLACE et al., 1982: CUFFNEY et al., 1984: DEWEY, 1986) demonstrated the potential hazards of pesticides to the aquatic insect community. Therefore, although herbicide and metal ion concentrations in stream B are not high, the colonization of leaf bags by Gammarus may be affected.

Because of hydrogeological constraints, it is possible that some periodic increases of contaminants, though not clearly detected in our analyses, occur in stream B. Furthermore, water quality in stream B has certainly been influenced by agricultural wastec and public activities nearby, and probably experienced periodic pollution over several years (CHENG, 1994). These longtime chronic exposures, even to moderate pollution. could explain the slower leaf breakdown at this site.

\section{ACKNOWLEDGEMENTS}

The financial support of the Secretariat for International
Cooperation (SCO) of the Cathoiic University of Louvain is gratefully acknowledged

\section{REFERENCES}

ABEL, T.H. \& F. BARLOCHER, 1984. Effects of cadmium on aquatic hyphomycetes. Appl. Environ. Microbiol., 48: 245 251.

AU, D.W.T.. I.J. HODGKISS \& L.L.P. VRIJMOED, 1992 Fungi and cellulolytic activity associated with decomposition of Bauhinia purpurea leaf litter in a polluted and unpolluted Hong Kong waterway. Can. J. Bot., 70: 1071-1079

BARLOCHER, F., 1985. The role of fungi in the nutrition of stream invertebratec. Bof.J. Linn. Soc., 91 : 83-94.

BARLOCHER, F. \& B. KENDRICK, 1974. Dynamics of the fungal population on leaves in a ctream. J. Ecol. . 62: 761791.

BERMINGHAM, S., L. MALTBY \& R.C. COOKE, 1996a Effects of coal mine effluent on aquatic hyphornycetea. I. Field study. J. Appl. Ecol.. 33: 1311-1321.

BERMINGHAM, S., L. MALTBY \& R.C. COOKE. 1996 b. Effects of coal mine effluent on aquatic hyphomycetes. II. Laboratory toxicity experiments. J. Appl. Ecol., 33: 1322-1328.

CHAMIER, A.C.. 1987. Effect of $\mathrm{pH}$ on microbial degradation of leaf litter in seven streams of English Lake District. Oecologia, $71: 491-500$.

CHABOT, A.G.. 1994. Géologie, hydrogeologie et zones de protection des captages. Geobel Conseil.

CHAUVET. E., 1987. Changes in the chemical composition of alder, poplar and willow leaves during decompocition in a river. Hydrobiologia, 148: 35-44

CHAUVET, E., E. FABRE. A. ELÓSEGUI \& J. POZO, 1997. The impact of eucalypt on the leaf-associated aqiiatic hyphomycetes in Spanish streamc. Cun.J. Bot., 75: 880-887.

CHENG, Z.L.. 1994. Etude d'un écosystème forestier: évaluation de la quulité du milieu aquatique du Bois de Lauzelle. Université Catholique de Louvain. Louvain-la-Neuve.

CHENG, Z.L., 1996. Contribution à l'étude de la réponse d'un milieu aquatique à l'habitat défavorable dans un écosystème forestier: Bois de Lauzelle. Université Catholique de Louvain, Louvain-la-Neuve.

CHERGUI, H. \& E. PATTÉE. 1991. An experimental ctudy of the breakdown of submerged leaves by hyphomycetes and invertebrates in Morocco. Freshwat. Biol.. 26: 97-110.

CUFFNEY, T.F., J.B. WALLACE \& J.R. WEBSTER, 1984. Pesticide manipulation of a headwater stream: invertebrate responses and their significance for ecosystem processes. Freshwat. Invert. Biol., 3: 153-171. 
CRANE, M., 1995. Effect of zinc on four populations and two generations of Gammarus pulex (L.). Freshwat. Biol., 33: 119-126.

CUMMINS, K.W., 1974. Structure and function of ctream ecosystems. BioScience: 24: 631-641.

DEGROOTE, E., 1997. Analyse et comparison de deux ecosystems forestiers. Université Catholique de Louvain, Louvain-la-Neuve.

DEWEY. S.L., 1986. Effects of the herbicide atrazine on aquatic insect community ctructure and emergence. Ecology, 67: 148-162.

GESSNER, M.O. \& E. CHAUVET, 1994. Importance of stream microfungi in controlling breakdown rates of leaf litter. Ecology, 75: 1807-1817.

GONCZOL, J., 1971. Aquatic hyphomycetec from the Börzsöny. Ann. Hist. Nat. Mus. Natl. Hung., 63: 57-75.

GRIFFITH, M.B. \& S.A. PERRY, 1993. Colonization and processing of leaf litter by macroinvertebrate shredders in streams of contrasting pH. Freshwat. Biol., 30: 93-103.

HALlAUX, B, 199.5. Pollution des eaux de Louvain-laNeuve par les herbicides. Université Catholique de Louvain, Louvain-la-Neuve.

HOWELLS, E.J., M.E. HOWELLS \& J.S. ALABASTER, 1983. A field investigation of water quality, fish and invertebrates in the Mawddach river system, Wales. J. Fish Biol., 22: 447469.

INGOLD, C.T., 1975. An illustrated guide to aquatic and water-borne hyphomycetes. Scientific Publication No. 30. Freshwater Biological Ascociation, Ambleside.

IQBAL, S.H., S.F. BHATTY \& K.S. MALIK, 1979. Freshwater hyphomycetec on decaying plant debris submerged in some streams of Pakistan. Trans. Mycol. Soc. Jap., 20: 51-61.

J.T. Baker Inc, 1990. Solid phase extraction for sample preparation. J.T. Baker Inc.

KAUSHIK, N.K. \& H.B.N. HYNES, 1968. Experimental study on the role of autumn-ched leaves in aquatic environments. J. Ecol., 56: 229-243

KAUSHIK, N.K. \& H.B.N. HYNES, 1971 The fate of the dead leavec that fall into streams. Arch. Hydrobiol., 68: 465-515.

LAMBERT, P., 1994. Recherche des causes de la pollution des eaux de captages par les herbicides U Louvain-la-Neuve. Université Catholique de Louvain, Louvain-la-Neuve.

MACKAY, R.J. \& J. KALFF, 1973. Ecology of two related species of caddisfly larvae in the organic substrates of a woodland ctream. Ecology, 54: 499-511.
MALTBY,L. \& M. CRANE, 1994. Recponsec of Gammarus pulex (Amphipoda, Crustacea) to metalliferous effluents: ldentification of toxic components and the importance of interpopulation variation. Environ. Pollut., 84: 45-52.

MAUND, S.J., E.J. TAYLOR \& D. PASCOE, 1992. Population recponcec of the frechwater amphipod cructacean Gammarus pulex (L.) to copper. Freshwat. Biol.,28: 29-36.

NILSSON, S., 1964. Freshwater hyphomycetes: taxonomy, morphology and ecology. Symb. Bot. Upsal., 18:1-130.

PETERSEN, R.C. \& K.W. CUMMINS, 1974. Leaf pack processing in a woodland stream. Freshwat. Biol., 4: 343-368.

PLÉNET, S., 1995. Freshwater amphipods as biomonitors of metal pollution in surface and interstitial aquatic cyctems. Freshwat. Biol.,33: 127-137.

POZO, J., E. GONZÁLEZ, J.R. DIEZ , J. MOLINERO \& A. ELÓSEGUI, 1997. Inputc of particulate organic matter to streams with different riparian vegetation. J. N. Am. Benthol. Soc., 16: $602-611$

SUBERKROPP, K. \& M.J. KLUG, 1976. Fungi and bacteria accociated with leaves during processing in a woodland ctream. Ecology, 57: 707-7 19.

SUBERKROPP, K. \& E. CHAUVET, 1995. Regulation of leaf breakdown by fungi in streams: Influence of water cheinistry. Ecology, 76: 1433-1445.

TACHET, H., M. BOURNAUD \& P. RICHOUX, 1987. Introduction U l'étude des macroinvertébrés des eaux douces: Systématique élémentaire et aperçu écologique. Université Lyon 1, Lyon.

TRISKA, F.J. \& J.R. SEDELL, 1976. Decompocition of four species of leaf litter in response to nitrate manipulation. Ecology, 57: 783-792.

WALLACE, J.B., J.R. WEBSTER \& T.F. CUFFNEY, 1982. Stream detritus dynamics: regulation by invertebrate consumers. Oecologia, 53: 197-200.

WEBSTER, J. \& E. DESCALS, 1981. Morphology, distribution, and ecology of conidial fungi in freshwater habitats. In: Biology of conidial fungi. (COLE, G.T. \& B. KENDRICJ, eds.): 295-355. Academic press, New York.

WILKINSON, L., 1990. Systat: the system for statistics. Systat, Evanston.

WOOD-EGGENSCHWILER, S. \& F. BARLOCHER, 1983. Aquatic hyphomycetes in cixteen streams in France, Germany and Switzerland. Trans. Br. Mycol. Soc., 81:371-379.

ZAR, J.H., 1984. Biostatistical Analysis. 2nd ed. PrenticeHall, Englewood Cliffc, London. 